\title{
SUPPORTING THE PROCESS OF AIRCRAFT MAINTENANCE WITH MOBILE DEVICES
}

\author{
Bartosz Brzozowski*, Karol KaWKa*, Krzysztof KaŹMIercZaK**, \\ ZDZisŁaW RochalA*, KONRAD WOJTOWICZ*
}

* Zakład Awioniki i Uzbrojenia Lotniczego, Wydział Mechatroniki i Lotnictwa, Wojskowa Akademia Techniczna (Department of Avionics and Air Armament, Faculty of Mechatronics and Aviation, Military University of Technology), ul. S. Kaliskiego 2, 00-908 Warsaw

** Zakład Technologii Inteligentnych, Instytut Podstawowych Problemów Techniki (Department of Intelligent Technologies, Institute of Fundamental Technological Research), ul. Adolfa Pawińskiego 5B, 02-106 Warsaw bartosz.brzozowski@wat.edu.pl, karol.kawka@outlook.com, kkazmier@ippt.pan.pl, zdzislaw.rochala@wat.edu.pl, konrad.wojtowicz@wat.edu.pl

\begin{abstract}
Maintenance of aircraft is a complex process and therefore, in order to optimize the process, integrated information systems are increasingly used. Rapid development and wide availability of mobile devices equipped with powerful processors and with a wide range of modern communication connections suggests their high usability for enterprise IT systems. In the Department of Avionics and Air Armament of the Military University of Technology (WAT) an ERP-class (Enterprise Resource Planning) system, intended to support aircraft maintenance [4] has been designed and developed. The main concept of the system is to store the aircraft related and maintenance information in a central repository, i.e. in databases hosted on a central database server. This solution ensures concurrent availability of the data to a large group of authorized users. The key components of the system include the database server and client applications, which ensure access to centralized information resources, according to assigned user rights. The project involves development of client applications using three technologies: web, desktop and mobile one. Developed client applications have successfully passed integration tests performed using sample maintenance data. Currently works on user authorization security and wireless data security are under way. Keywords: maintenance system, mobile application, aircraft.
\end{abstract}

\section{INTRODUCTION}

Proper maintenance of aircrafts involves their reasonable operation and maintenance, which should ensure their reliable operation in air. In order to meet these requirements and to achieve appropriate safety level, it is necessary to follow manufacturer-specified operational standards 
and other rules resulting from specific conditions, in which the aircraft are operated $[9,10]$. One shall be aware that the accessories industry involves high costs. Any delays, prolonging periods when the aircrafts are unfit for flight may generate enormous financial losses. Therefore it is important to efficiently optimize the maintenance process, which can be successfully supported by computer technologies. Along with development of the technology, the possibilities for larger automation and computer aided maintenance process have been emerging. Gradual elimination of extensive paper-based documentation and its substitution with electronic versions has resulted with improved transparency, better and less restricted access to stored maintenance documentation and has facilitated order-keeping and ongoing updates. Algorithms, which validate the information being entered, help eliminating human errors. Therefore extensive information systems are being developed, which would support comprehensive management of whole organizations operating aircraft fleets [3].

Also, mobile applications are now more and more often used in systems employing databases. Today, almost every bank, every mobile network operator and majority of on-line stores have developed their dedicated mobile applications. A mobile app uses a common database and ensures secure access to data stored there. For users, this is a very convenient solution as it lets them access the system from anywhere in the world. Mobile technology has found its application in aviation industry as well. It is used both in civil applications as well as in military aviation[7]. For example selected iOS and Android devices may access the internal wireless network of US Air Force[8], mobile solutions are also used for maintenance of UAVs [1, 2].

In order to ensure the maximum efficiency of the integrated maintenance system, it is necessary to assure its unrestricted availability to authorized users. Due to the nature of maintenance work performed in the aviation industry, the best solution would be to employ mobile devices, which would allow wireless communication with the system. The devices would connect to the data server on a regular basis, to ensure that the information available to their users is up-to-date. The main advantage of this solution would be the ability to immediately enter to the system the information on completed maintenance works, which would significantly accelerate execution of subsequent works. A mobile device could be used to plan and to organize the work of individual system users. A mobile application might also be a medium that would provide the technical documentation necessary to standardize the maintenance processes, sometimes supplementing very extensive and inconvenient paper-based documentation resources.

\section{SYSTEM DESIGN}

Based on the conducted analysis of the maintenance process of a selected aircraft, a set of sample maintenance data for the designed system has been developed. At the current stage, it was necessary to implement a demo data package, in order to demonstrate the performance of the system. Therefore, from the broad range of information, only a representative sub-set of data has been selected and work has been focused on periodical maintenance activities related to avionics, based on the Unified Set of Maintenance Procedures (JZOT) of the W-3 Sokól Helicopter. 
The main advantage of the system is its mobility. Mobile applications play key role and the design of subsequent components has been dictated by the requirement to adapt them to the mobile version. In order to allow simultaneous use of data resources by many users, it is necessary to properly configure the server and databases it hosts. A tool to manage the data is also necessary. It is planned that there will be several administrators working in the system and all of them should be able to perform operations on data

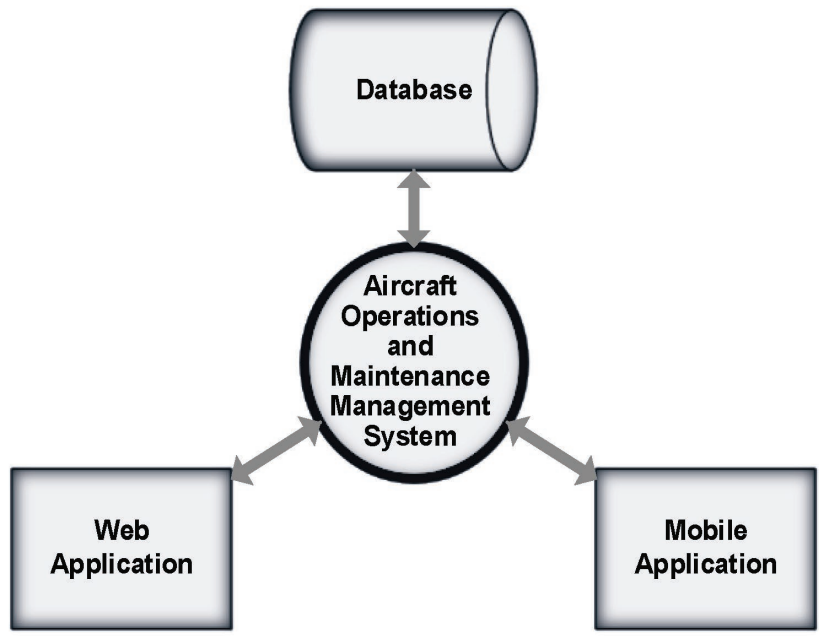

Fig. 1. System structure diagram [Kawka, 2016] Concurrently. For this purpose, a web application has been developed, intended primarily for administration and for management of user access rights. The system structure diagram is shown in Fig. 1.

\subsection{Operational information database}

The database is hosted on the Microsoft SQL Server 2014 database server. SQL Server

AWE_database

$\oplus \square$ Database Diagrams

$\square \square$ Tables
田 System Tables
由 FileTables
由 国 dbo.Uiztkownicy
(7) 国 dbo.Harmonogram
由 国 dbo.Plan
由 国 dbo.Obsługi
甲国 dbo.Wykorzystanie środków
丹国 dbo.Resurs techniczny
(7) 国 dbo.Ewidencja
由 国 dbo.Czẹści numerowane
(7) 国 dbo. Historia lotów
(7) 国 dbo.Karty technologiczne
由 国 dbo.Mapy magazynu

Fig. 2. The list of tables in the customer database [Kawka, 2016]
Management Studio is used to design and to manage the data. The server has been configured to work in a local wireless Wi-Fi network, which allowed to test the application performance across various devices.

Data is stored in 11 tables (Fig. 2), which contain the information necessary for proper operation of key system functions. The structure of the database has been designed so that it can be easily adapted for the Polish Air Force. At the same time, it will be possible to continue its development by adding new or by modifying its existing tables, which is assumed to happen in future.

All database operations are performed using stored procedures, i.e. sets of instructions and commands are executed directly on the server. Individual commands do not have to be transmitted over the network individually, which in consequence

significantly reduces the network traffic, as only the name of the stored procedure and its parameters, if any, are being sent[5]. The T-SQL query language has been used to develop the procedures. 


\subsection{Web Application}

The web application has been developed in the MVC (Model-View-Controller) technology, with the server-side application logic (controller) developed in PHP, and web-based part (i.e. the code executed by web browsers) developed in the JavaScript with the AngularJS framework. Graphical effects have been coded using CSS and the Bootstrap framework. With the help of the XAMPP environment, the website was published in the local Wi-Fi network, which allowed for system-wide testing.

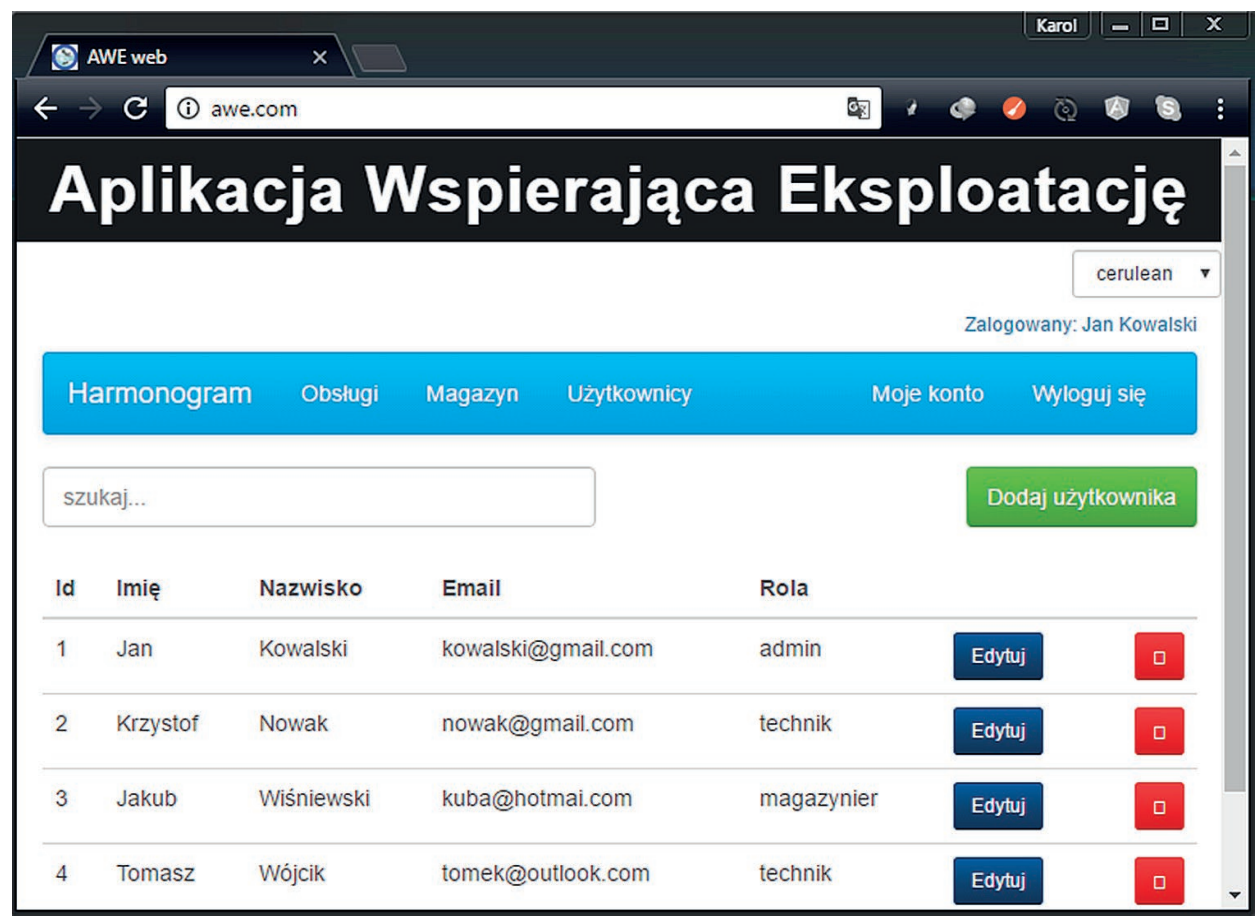

Fig. 3. Web application - user management functions [Kawka, 2016]

The main functions of the web application include:

- defining new users and editing their personal data (Fig 3);

- scheduling periodical maintenance;

- changing maintenance activities and their methods;

- warehouse management, order placement.

Basic methods of the application were verified on ongoing basis by designed unit tests and the entire module successfully passed integration tests using sample set of the maintenance data.

\subsection{Mobile Application}

The mobile application runs on Android mobile devices. It has been developed in Android Studio, using a JAVA-based object-oriented programming environment and XML[6]. The main 
task of the application is to help users in aircraft maintenance activities. To do this, it was necessary to utilize hardware resources of mobile devices, on which the application is deployed - i.e. its sensors, such as: NFC (Near Field Communication) for user identification, Wi-Fi for wireless database connection and camera for identification of the photo-code.

User identification process utilizes proximity cards. When the card is brought near the device, the card's code, unique for each user is being read using its NFC sensor. The next stage of the verification involves password entry (Fig. 4). As a result, the information entered to the system is validated and appropriate user profile is opened, permitting access to the information according to the user's permissions.

The application design is divided into two parts, dedicated to various types of users. Therefore the following user profiles are distinguished:

- Engineer - the target user is a member of the technical personnel, who performs periodic maintenance. Having logged into the application, a user is presented with the application menu and data with tasks assigned to the specific user are loaded.

- Warehouseman - the target user is the warehouseman, who issues and receives parts and material resources from/to warehouse inventory records. The main advantage of this part of the application is the photocode scanner, which significantly facilitates product identification.

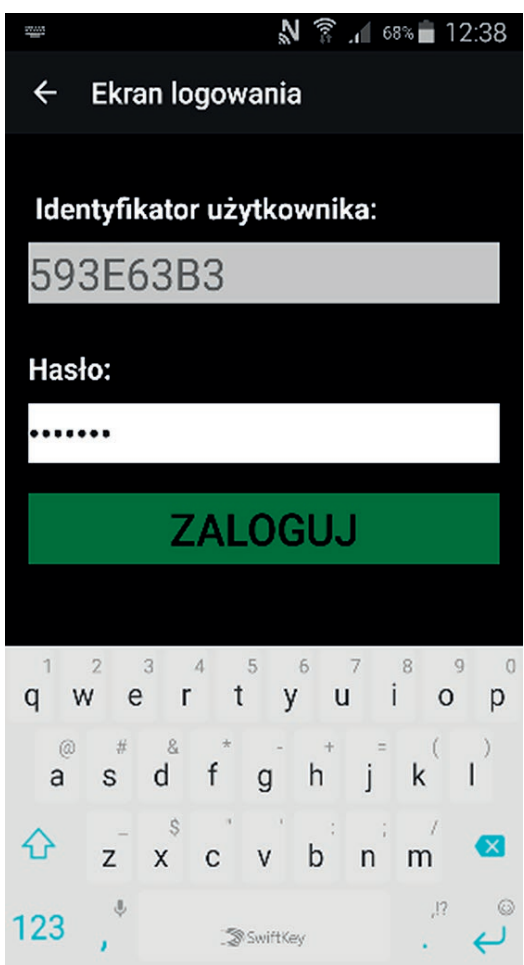

Fig. 4. Mobile application - user identification [Kawka, 2016]

\section{MOBILE APPLICATION FUNCTIONALITY}

The basic feature of the designed mobile application, being one of the components available to users, is the option to grant access to the central data repository from anywhere in the world. In addition, proper use of the hardware resources of the platform on which the application is installed, allows to provide a number of facilities, which streamline physical work on the equipment.

\subsection{Engineer's Profile}

The functionality of the Engineer's Profile is described using the UML modeling language diagram (Fig. 5). 


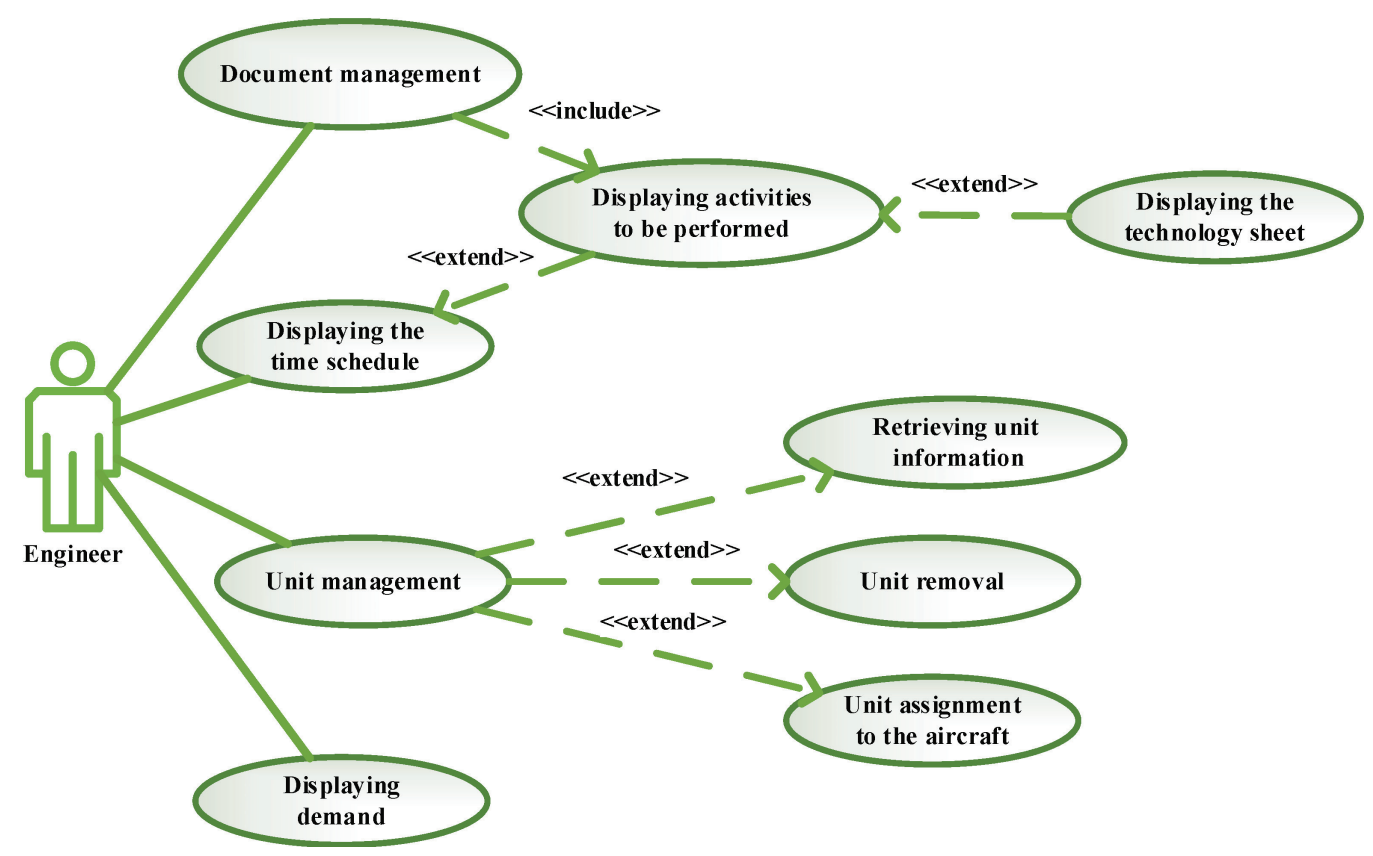

Fig. 5. Use Case Diagram (UML) - Engineer's Profile [Kawka, 2016]

The Engineer profile includes the following functions:

- Document management

This function displays guidelines describing how the predefined maintenance work should be performed (see in Fig. 6.a). It is a useful tool, which sometimes can replace very extensive paper-based documentation. The Engineer may at any time check the aircraft manufacturer's recommendations related to execution of a specific activity. In case of paper-based documentation, this would be more difficult, as usually the documentation is too large to be always available on hand. It also significantly simplifies updates and modifications of the documentation. In aviation industry, as a result of events occurring during the aircraft operation, which are unforeseen at the time of the aircraft design, bulletins are very often published, which contain recommended modifications to aircraft usage patterns. In case of electronic documentation, such changes may be made by the manufacturer very easily. They just need to update the database. Also, it is very important that the user always uses the current version of the documentation, in the form of an consolidated document, and that updates are performed without user involvement.

- Displaying the time schedule

This function displays the plan of tasks that the engineer must perform on a given day. It displays categories of activities from specific periodical maintenance service procedure and the id of the aircraft, in which the service task is to be performed (Fig. 6.b). User may review all actions of any category by pressing the "ACTIVITY LIST" button. They may also load a technology sheet, which details performance of the activity in question (Fig. 6.c). 


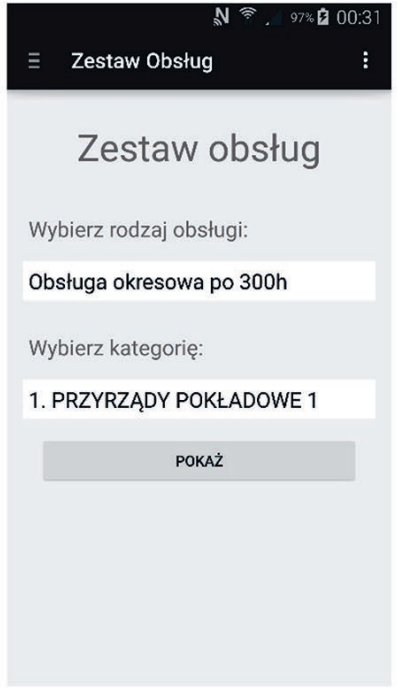

b)

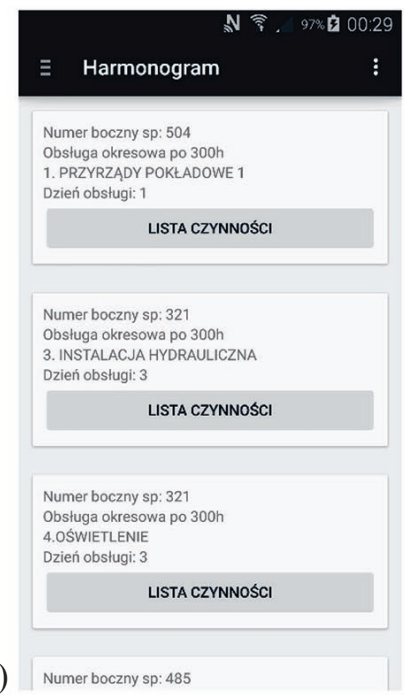

N 2 , $83 \%$ บ $76: 34$
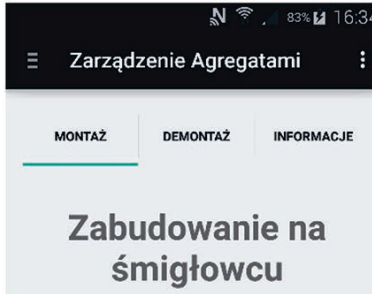

Numer statku powietrznego:

SP: 231

\section{$\underline{\text { numer seryjny }}$}

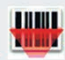

\section{ZATWIERDŹ}

d)

e)
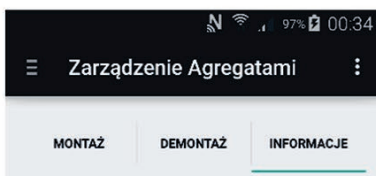

\section{Informacje 0 agregacie}

$\frac{5457 h 5456823}{\text { POKAŻ }}$

Opis: Prądnica prądu przemiennego GT40PC28B

Opis szczegółowy: brak

Data montażu na sp: 2015-04-16

Pozostały resurs godzinowy: 90

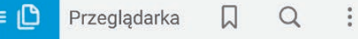

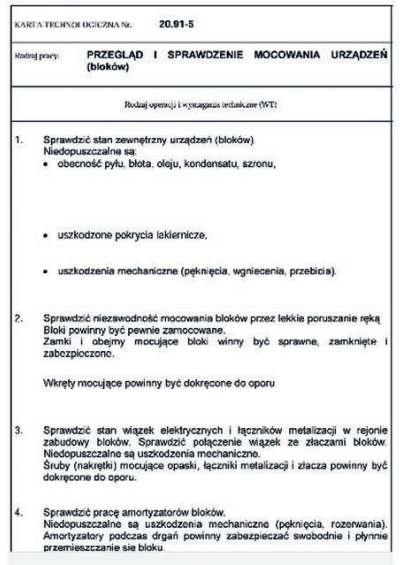

c)

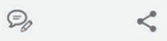

Fig. 6. Screenshots showing functions of the engineer's profile: a) documentation management; b) schedule viewing; c) technology sheet viewing; d) unit management - installation; e) unit management - unit information; f) demand [Kawka, 2016]

- Unit management

This function allows the user to manage the available units and their relationships with the aircraft. Replacement of all sub-assemblies in the aircraft is recorded. This allows users to determine the remaining service life of each subassembly or component and thus to verify whether the given element should be replaced during the maintenance or not. User 
may assign a specific unit to an aircraft. User selects the unit from the list of available units in the database (Fig. 6.d) and then enters or scans its serial number using a barcode/photocode scanner. When "ACCEPT" button is pressed, the association is committed to the database. When an element is being disassembled, the relevant information shall also be entered to the system. The next tab allows to delete the association between the disassembled unit and the aircraft. User just needs to enter the serial number and the association will be removed from the database, after confirmation.

The application allows users to preview all information available in the database related to a specific part. After a unit's serial number is entered, all information related to it is downloaded from the database (Fig. 6.e).

- Displaying demand

This function shows the list of parts and material resources, which are required to perform tasks assigned to the engineer. A specific item is displayed along with its part number and the planned use date (Fig. 6.f). This allows the user to prepare necessary materials before commencing with the maintenance work.

\subsection{Warehouseman's Profile}

The functionality of the Warehouseman's Profile is described using the UML modeling language diagram (Fig. 7).

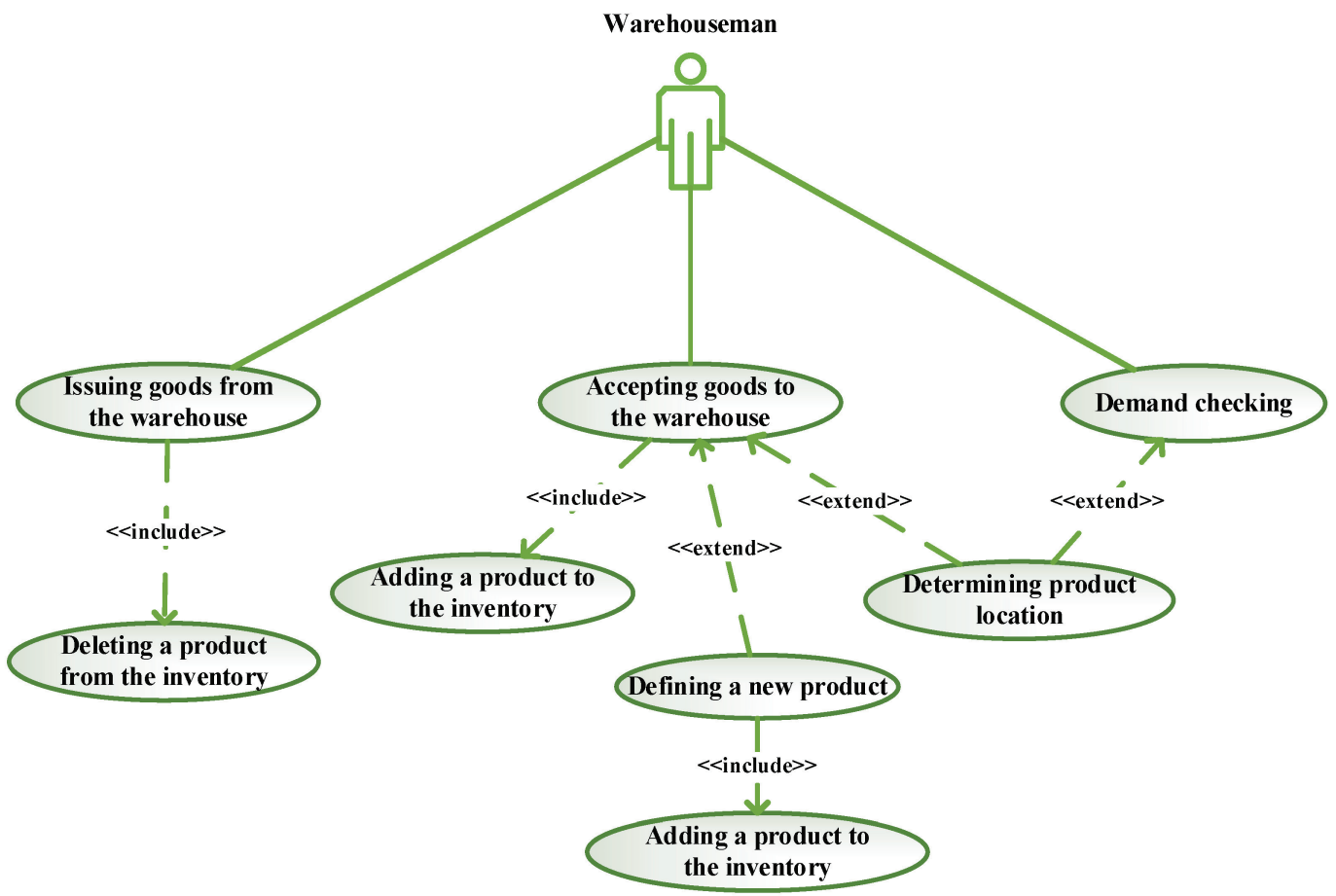

Fig. 7. Use Case Diagram (UML) - Warehouseman's Profile [Kawka, 2016] 
The Warehouseman profile includes the following functions:

- Issuing goods from the warehouse.

This function allows automatic removal of a product from the inventory when, it is issued from the warehouse. User has to enter the product code into the relevant text field or scan the barcode/ photocode. Having entered the part number and the quantity (Fig. 8.a), or in case of a product without an id/without the serial number, by pressing the "DELETE" button the product can be deleted from the inventory.
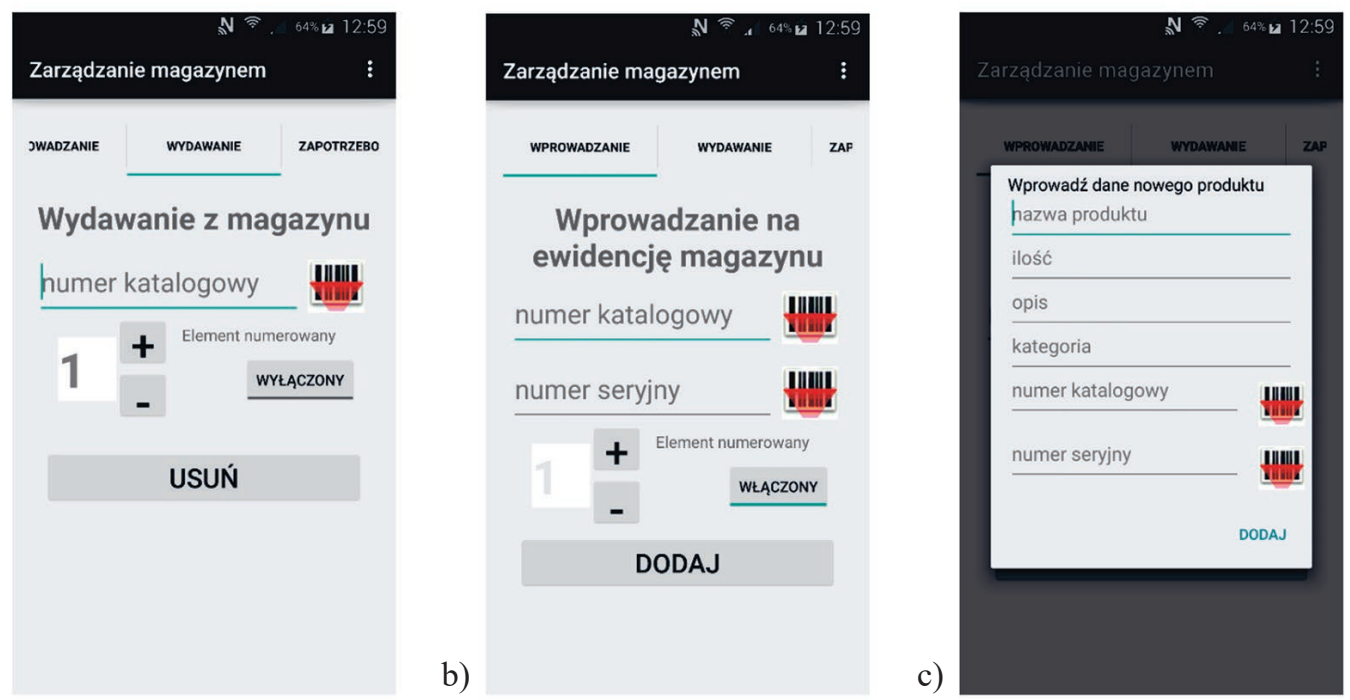

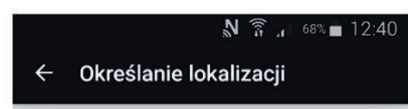

Strzałka wskazuje docelową lokalizację:

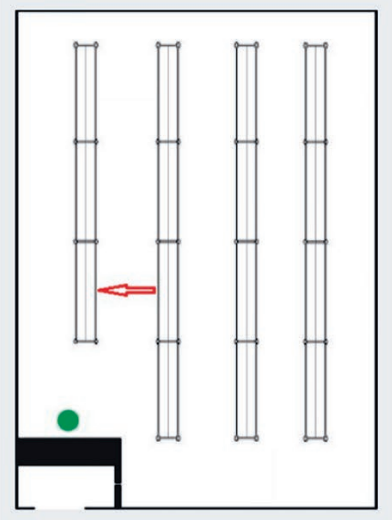

d)

Fig. 7. Screenshots showing functions of the warehouseman's profile: a) issuing from the warehouse; b) entering to the inventory; c) defining a new product; d) specifying its location; e) checking demand [Kawka, 2016] 
- Accepting goods to the warehouse

This function allows user to enter to the system the information on product's receipt into the warehouse. This is the most advanced tool in the warehouseman's profile. The user, while entering the product, may choose one of the three options:

- adding a specific quantity of products with the same part number;

- adding a specific numbered product; in this case the user enters the part number and the serial number (Fig. 8.b);

- entering a new product, not yet defined in the product database (Fig. 8.c). In this case, the user does not have to enter all the required information in the application window; but instead he or she may enter a more detailed description using the web version of the system.

When a predefined product is added, the "SHOW TARGET LOCATION" button will appear on the screen. User may view its location in the warehouse. It displays the warehouse map (Fig. 8.d), with an arrow indicating the location where the product should be located. In the same way, as in the case of "ISSUING", a barcode/photocode scanner can be used for entering the part number or serial number.

- Demand checking

The function generates a list of parts and material resources required to carry out next periodic maintenances (Fig. 8.e). Warehouseman has predefined products, which he or she is going to issue from the warehouse soon. He or she may also check the location of the given product in the warehouse. When the "WAREHOUSE LOCATION" button is pressed, a map with the product location marked will be displayed (Fig. 8.d).

The Android Testing Support Library, a part of the Android Studio environment, has been used during development of the application, to perform unit testing of individual methods of the application, in order to validate their operation on ongoing basis. Functional tests were performed by users not involved in the system development. Users worked on sample maintenance data resources, trying to execute all scenarios described in the user documentation of the application. Performed tests revealed a number of errors and weak points and they significantly contributed to proper functioning of the current version of the application.

\section{CONCLUSION}

The paper presents a concept of a new methodology of managing the maintenance process using integrated IT systems. An architecture was designed to demonstrate the applicability of mobile devices in the aircraft maintenance processes. A relatively easy-to-use client application has been obtained, which significantly contributes to improvement of the aircraft maintenance personnel's working conditions. They provide users with access to stored maintenance data using a mobile platform based on the common Android system or using a web browser. In addition, in both applications an intuitive graphical user interface (GUI) has been implemented.

Based on the review of existing ERP-class systems and on conducted validation tests of the developed application, one may notice fundamental benefits of mobile devices applications for aircraft maintenance. First of all, the use of such solution makes it possible to supplement 
the paper-based documentation with its digital equivalent stored in central data repositories, which can be accessed by an authorized logged user. Additionally, imposition of the specific order of works to be executed during maintenance, has allowed to greatly minimize the risk of errors resulting from unavailability of up-to-date guidelines.

\section{REFERENCES}

[1] Brzozowski, B., Sobieraj, W. and Wojtowicz, K., 2013, "Simulation Method of UAV Avionics System Optimization. Solid State Phenomena", 198, pp. 238-242.

[2] Brzozowski, B., Sobieraj, W. and Wojtowicz, K., 2013, UAV Avionics System Software Development Using Simulation Method. Solid State Phenomena, 198, pp. 260-265.

[3] Ważny, M. and Wojtowicz, K., 2008, The analysis of the military aircraft maintenance system and the modernization proposal. Maintenance and Reliability 3(39), pp. 4-11.

[4] Kawka, K., 2016,'Projekt aplikacji mobilnej ułatwiającej dostęp do systemu zarządzania danymi eksploatacyjnymi statków powietrznych" (Design of a mobile application facilitating access to aircraft operational data management system). Engineering Master's Thesis, WAT (Military University of Technology).

[5] Dewson, R., 2015, SQL Server: Wstęp dla programistów (SQL Server. Introduction for software developers), Wydawnictwo HELION (Helion Publishing House).

[6] Wantoch-Rekowski, R., 2014, Android w praktyce: projektowanie aplikacji (Android in practice: application development), Wydawnictwo Naukowe PWN (PWN Scientific Publishing House).

[7] Transforming airline operations at airports using handheld devices, SITA, 2010.

[8] <https://defensesystems.com/>

[9] JZOT śmigłowca W-3 wszystkich typów i wersji, osprzęt, wydanie drugie - Dokument Nr AE - 36. (Unified Set of Technical Maintenance Procedures for W-3 helicopter, all types, and versions, accessories, 2nd edition, Doc. No. AE - 36) 06.18.0JZOT.

[10] EASA Part-145.

\section{WYKORZYSTANIE URZĄDZEŃ MOBILNYCH DO WSPIERANIA PROCESU OBSLUGI STATKÓW POWIETRZNYCH}

\section{Streszczenie}

Eksploatacja statków powietrznych jest procesem złożonym, dlatego w celu jej optymalizacji coraz powszechniej wykorzystuje się zintegrowane systemy informatyczne. Szybki rozwój i szeroka dostępność urządzeń mobilnych wyposażonych w wydajne procesory oraz szeroką gamę nowoczesnych łączy komunikacyjnych sugeruje ich wysoki poziom użyteczności w systemach informatycznych przedsiębiorstwa. W Zakładzie Awioniki i Uzbrojenia Lotniczego WAT zaprojektowano i rozpoczęto budowę systemu klasy ERP (ang. enterprise resource planning) 
przeznaczonego do wspomagania procesu eksploatacji statków powietrznych [4]. Główną ideą systemu jest przechowywanie informacji o statkach powietrznych i procesie obsługi w jednym miejscu, w bazach danych zlokalizowanych na centralnym serwerze baz danych. Dzięki takiemu rozwiązaniu dostęp do danych może być realizowany jednocześnie przez szerokie grono uprawnionych użytkowników. Głównymi elementami składowymi systemu są serwer baz danych oraz aplikacje klienckie pozwalające na dostęp do centralnych zasobów informacji w zakresie uprawnień użytkownika. Projekt zakłada wykonanie aplikacji klienckich w trzech technologiach: webowej, desktopowej oraz przeznaczonej na urządzenia mobilne. Opracowane aplikacje klienckie pomyślnie przeszły testy integracyjne zasilone zbiorem przykładowych danych obsługowych. Obecnie trwają prace nad problemem bezpieczeństwa autoryzacji użytkownika oraz bezprzewodowej transmisji danych.

Słowa kluczowe: system eksploatacji, aplikacja mobilna, statek powietrzny. 